\title{
Potencjalności aktywne jako kompetencje społeczne - profil psychologiczny studentów medycyny w koncepcji transkulturowej psychoterapii pozytywnej
}

\section{Actual capabilities as social competencies - psychological profile of medical students in the concept of Transcultural Positive Psychotherapy}

\author{
Aleksandra Zarek ${ }^{1 凶}$, Anna Wyszadko² \\ ${ }^{1}$ Uniwersytet Medyczny im. Piastów Śląskich we Wrocławiu, Zakład Humanistycznych Nauk Lekarskich, ul. J. Mikulicza-Radeckiego 7, 50-368 Wrocław \\ Medical University in Wroclaw, Department of Humanistic Medical Sciences \\ ${ }^{2}$ Gdański Uniwersytet Medyczny, Zakład Medycyny Paliatywnej, ul. Dębinki 2, 80-211 Gdańsk \\ Medical University of Gdańsk, Department of Palliative Medicine \\ $\bowtie$ aleksandra.zarek@umed.wroc.pl
}

\begin{abstract}
Introduction: Social competencies are an important aspect of a physician's work. These skills facilitate building doctorpatient relationships, conducting culturally competent medical interviews, fostering the realization of diagnostic as well as therapeutic tasks, and enhancing the physician's well-being. The work aimed at recognizing the social competencies of medical students with consideration of the cultural aspect.

Materials and methods: The theoretical background for the analysis of social competencies was the concept of Transcultural Positive Psychotherapy proposed by Nossrat Peseschkian, and describing actual capabilities, recognized in this work as competencies. The study involved 133 students of the Medical Faculty, Medical University in Wroclaw - 47 from the Polish Division and 86 from English Division. The Wiesbaden Inventory for Positive Psychotherapy and Family Therapy (WIPPF2) was used as a research tool.
\end{abstract}

Results: Most actual capabilities in the group under study were properly differentiated (balanced). Students identified themselves most strongly with hope, politeness, love, reliability and justice. In comparison to students of the English Division, Polish students identified themselves the least with the capabilities of order, politeness, obedience, faithfulness, patience and contact, and the most with reliability. Women put more importance on politeness, justice, trust and faith/sense than men did. Students that were in partnerships valued openness/honesty, contact, tenderness/sexuality, love and hope more than single respondents.

Conclusions: It is recommended to incorporate cultural knowledge in the education of Polish medical students, as well as to encourage the mindset of openness and curiosity towards the cultural determinants of patients' health.

Keywords: social competence; doctor-patient relationship; medical students.

\begin{abstract}
ABSTRAKT
Wstęp: Kompetencje społeczne są istotnym elementem pracy lekarzy. Te umiejętności ułatwiają budowanie relacji z pacjentem, prowadzenie wrażliwego kulturowo wywiadu medycznego, sprzyjają realizowaniu zadań diagnostycznych i terapeutycznych oraz pozwalają zadbać o własny dobrostan psychiczny. Celem pracy było poznanie kompetencji społecznych studentów medycyny, z uwzględnieniem aspektu kulturowego.

Materiały i metody: Podstawą teoretyczną analizy kompetencji społecznych była koncepcja transkulturowej psychoterapii pozytywnej autorstwa Nossrata Peseschkiana, w której opisano potencjalności aktywne, ujmowane w niniejszej pracy jako kompetencje. W badaniu wzięło udział 133 studentów Wydziału Lekarskiego Uniwersytetu Medycznego we Wrocławiu, przy czym 47 osób studiowało w języku polskim, a 86 osób było uczestnikami English Devision. Jako narzędzie pomiarowe wykorzystano Wiesbadeński Kwestionariusz Psychoterapii Pozytywnej i Rodzinnej (Wiesbaden Inventory for Positive Psychotherapy and Family Therapy - WIPPF2).
\end{abstract}

Wyniki: W badanej grupie studentów większość potencjalności aktywnych była odpowiednio zróżnicowana (zbalansowana). Znaczną identyfikację badani ujawnili względem: nadziei, uprzejmości, miłości oraz niezawodności i sprawiedliwości. W porównaniu z osobami studiującymi w języku angielskim studenci polscy mniej (lub najmniej) identyfikowali się z potencjalnościami: porządku, uprzejmości, posłuszeństwa, wierności, cierpliwości i kontaktu, a najbardziej - z niezawodnością. Kobiety przywiązywały większą wagę do uprzejmości, sprawiedliwości, zaufania oraz wiary/sensu niż mężczyźni. Osoby pozostające w związkach nadawały większe znaczenie niż osoby wolne takim potencjalnościom jak: otwartość/szczerość, kontakt, czułość/ seksualność, miłość, nadzieja.

Wnioski: Zaleca się włączenie w proces edukacji studentów polskich wiedzy na temat innych kultur oraz rozbudzanie postawy ciekawości i otwartości wobec kulturowych uwarunkowań zdrowia pacjenta.

Słowa kluczowe: kompetencje społeczne; relacja lekarz-pacjent; studenci medycyny. 


\section{WSTĘP}

Termin „kompetencja” (competence) wprowadził do literatury psychologicznej Robert White, psycholog amerykański, który rozumiał to pojęcie jako zdolność jednostki do efektywnej interakcji z otoczeniem nabywaną w procesie uczenia się, a nie jedynie dojrzewania [1]. Wykonywanie zawodu lekarza wymaga wykształcenia wielu różnych kompetencji, gdyż od absolwenta studiów na kierunku lekarskim oczekuje się posiadania aktualnej i specjalistycznej wiedzy medycznej oraz umiejętności pozwalających na postawienie prawidłowej diagnozy i wdrożenie odpowiedniej procedury terapeutycznej. Musi on także korzystać z umiejętności społecznych, do których należą: nawiązanie i utrzymanie głębokiego oraz pełnego szacunku kontaktu z chorym, kierowanie się przede wszystkim dobrem chorego, przestrzeganie tajemnicy lekarskiej i praw pacjenta, umiejętność stałego dokształcania się oraz świadomość własnych ograniczeń [2]. Ważnym aspektem pracy lekarza jest pozostawanie w kontakcie z osobami chorymi, dlatego kluczowymi kompetencjami w tym zawodzie są te, które umożliwiają podkreślanie podmiotowości pacjenta, wyrażanie troski i gotowości do niesienia mu pomocy, a także wspieranie oraz motywowanie go do pozostania w planie leczenia, a samemu lekarzowi pozwalają zadbać o własny dobrostan psychiczny [3]. Pacjenci lekarzy bardziej kompetentnych społecznie częściej stosują się do zaleceń lekarskich [4]. Jednocześnie lekarze o większych kompetencjach rzadziej doświadczają objawów wypalenia zawodowego, takich jak: wyczerpanie emocjonalne (emotional exhaustion), dystansowanie emocjonalne (emotional detachment) oraz dehumanizacja (dehumanization), i zarazem bardziej korzystnie oceniają własne dokonania (personal accomplishment) [5].

We współczesnych, partnerskich modelach relacji pomiędzy lekarzem i pacjentem opisuje się szczegółowo konkretne umiejętności relacyjno-komunikacyjne sprzyjające realizowaniu przez lekarza określonych celów procesu diagnostyczno-terapeutycznego [6, 7, 8]. Do najważniejszych zalicza się: słuchanie, komunikowanie, prowadzenie, dostrojenie, odzwierciedlanie, autentyczność, empatię, dystans interpersonalny, neutralność, autoprezentację, konfrontowanie, informowanie i edukowanie, wspieranie, interweniowanie w kryzysie, rozwiązywanie problemów i podejmowanie decyzji, zmianę zachowania, motywowanie, negocjowanie, asertywność, wgląd i refleksyjność [3].

Określone kompetencje osobiste są cenione u przyszłych lekarzy już na etapie rekrutacji na studia medyczne, gdyż ich posiadanie ułatwia osiągnięcie sukcesu w procesie edukacji. Jako najważniejsze wskazuje się: etyczną odpowiedzialność za siebie i innych, rzetelność i niezawodność, zorientowanie na pomoc innym (service orientation), umiejętności społeczne, zdolność samodoskonalenia, odporność i zdolność do przystosowania się (adaptability), kompetencję kulturową (cultural competence), komunikację słowną i pracę zespołową [9]. Praktykujący lekarze także dostrzegają potrzebę rozwijania psychologicznych kompetencji w celu poprawy jakości swojej pracy, w szczególności takich jak: umiejętność komunikowania się z pacjentem (31\%), dostarczanie mu wsparcia
(12\%) i motywowania go do leczenia (6\%), a także umiejętność oddzielania życia zawodowego i prywatnego (6\%) oraz rozwijanie własnej asertywności (45\%) [10].

To, co rozumiane jest pod pojęciem kompetencji społecznych, bywa przez różnych badaczy określane w rozmaity sposób (np. kompetencje komunikacyjne, kompetencje relacyjne, kompetencje do efektywnego działania, zdolności społeczne i komunikacyjne, umiejętności społeczne, umiejętności komunikacyjne, umiejętność adaptacji albo po prostu kompetencje psychologiczne), ale wspólne im jest przekonanie, iż wskaźnikiem tych kompetencji jest efektywność funkcjonowania w rzeczywistych sytuacjach społecznych. Wśród kryteriów tej efektywności najczęściej wymienia się: skuteczność w osiąganiu przez jednostkę własnych celów, umiejętność budowania więzi interpersonalnych, brak nadmiernych kosztów psychologicznych i psychofizjologicznych oraz adekwatność zachowań w stosunku do standardów społecznych [3,11]. Podkreśla się, że kompetencje społeczne są nabywane w toku treningu społecznego oraz zakłada się ich specyficzny, a nie ogólny charakter, co oznacza, że dana osoba może dobrze radzić sobie z jednym typem sytuacji społecznej, ale nie radzić sobie w sytuacjach innego rodzaju $[11,12,13]$. Warto zaznaczyć, iż proces celowego treningu określonych umiejętności społecznych - realizowany np. w kontekście szkolenia zawodowego - powinien uwzględniać zarówno intelektualne (np. inteligencja emocjonalna), jak i temperamentalno-osobowościowe (np. odporność na pobudzenie, ekstrawersja/introwersja, neurotyczność, sumienność, zadaniowy styl radzenia sobie ze stresem) cechy osób w nim uczestniczących, ponieważ mają one wpływ na efektywność tego procesu $[11,14,15]$.

W piśmiennictwie podkreśla się znaczenie samowiedzy lekarza jako elementu kształtującego jakość wzajemnej relacji oraz komunikacji pomiędzy lekarzem i pacjentem. Cechy osobowości lekarza ujawniają się w sposobie prowadzenia wywiadu z pacjentami, dlatego w efekcie wpływają na ilość i jakość pozyskiwanych informacji, rodzaj powstających relacji oraz możliwość oddziaływania na motywacje i zachowania osób chorych. Praca psychologiczna polegająca na pogłębianiu samoświadomości, rozwijaniu sfer życia wzmagających poczucie dobrostanu oraz dbaniu o własne potrzeby w kontakcie z osobami chorymi (self-care) umożliwia lekarzowi odpowiedzialne włączenie osobistych zasobów w proces leczenia pacjentów [16]. Dotyczy to również uwzględniania kulturowego aspektu kontaktu pomiędzy lekarzem i pacjentem.

Prowadzenie kompetentnego kulturowo wywiadu medycznego zazwyczaj rozumie się poprzez pryzmat uwzględniania takich aspektów kulturowego doświadczenia pacjenta, jak przynależność rasowa, płeć, religia, narodowość, język, wykształcenie czy zawód, jednak w praktyce każde spotkanie z pacjentem (o ile oczywiście nie jest on lekarzem) powinno być postrzegane z perspektywy międzykulturowej. $\mathrm{W}$ rezultacie kształcenia i treningu zawodowego lekarz rozumie procesy chorobowe i opisuje je w sposób, który może być niezgodny z perspektywą, czyli tzw. modelem wyjaśniającym (explanatory model) pacjenta; w celach diagnostycznych personel medyczny wykorzystuje procedury lub technologie obce pacjentowi. 
Kulturowo kompetentnej opieki medycznej może dostarczać zespół terapeutyczny, a w szczególności lekarz, który ma świadomość tych odmienności, wykazuje gotowość, by aktywnie poznawać perspektywę pacjenta i wspólnie z nim analizować zarówno implikacje osobistego modelu wyjaśniającego, jak i kontekst zaordynowanego leczenia [17]. Stąd postuluje się, by włączać te umiejętności do procesu edukacji studentów medycyny [18].

Kompetencje społeczne są istotnym elementem kompetencji zawodowych lekarzy [19, 20] i przez nich samych też tak są postrzegane [21]. Poznawanie tych właściwości osób przygotowujących się do zawodu lekarza jest niezbędne do oszacowania ich potrzeb w zakresie specjalistycznego treningu, jak również konstruowania programów edukacyjnych.

Celem niniejszej pracy było poznanie kompetencji społecznych przyszłych lekarzy, w tym kompetencji relacyjnych, z uwzględnieniem aspektu kulturowego. Badanie miało charakter eksploracyjny.

\section{MATERIAtY I METODY}

W niniejszej pracy podstawą teoretyczną analizy kompetencji społecznych była koncepcja transkulturowej psychoterapii pozytywnej (TPP) Nossrata Peseschkiana, która jest integracyjną metodą terapeutyczną łącząca elementy psychoterapii humanistycznej, psychodynamicznej, systemowej, poznawczo-behawioralnej i zarazem szkołą psychoterapii powstałą w 1968 r. w Niemczech. Jej założyciel, z pochodzenia Pers, szkołę medyczną ukończył w Niemczech, tam też mieszkał i pracował przez resztę swojego życia, tj. do 2010 r. Był neurologiem, psychiatrą i psychoterapeutą, szczególnie wrażliwym na kontekst kulturowy i treść trudności doświadczanych przez swoich pacjentów [22, 23, 24]. Jego zdaniem konflikty - zarówno międzygrupowe czy interpersonalne, jak i intrapersonalne (wewnętrzne) - wynikają z odmienności lub ambiwalencji w stosunku do ważnych aspektów rzeczywistości, określonych pod względem treści, opisujących przekonania, oczekiwania oraz normy zachowania, jakie przyswajamy w procesie wychowania i edukacji w określonym (kulturowo i rodzinnie) kontekście społecznym. Nazwał je potencjalnościami aktywnymi (actual capabilities capacities), pragnąc uwypuklić, że stanowią wrażliwe punkty naszej osobowości (mają duże znaczenie), a ponieważ uaktywniają się w kontekście codziennych interakcji społecznych, z łatwością mogą stać się przyczyną naszej frustracji [25]. Peseschkian wskazywał na dwa rodzaje potencjalności - podstawowe (basic) i wtórne (secondary), będące efektem różnicowania się dwóch immanentnych człowiekowi zdolności - do miłości (tworzenia relacji) i do poznania. Pisał on, że w potencjalnościach wtórnych są odzwierciedlone normy społeczne grupy, z której pochodzimy, które wiążą się z potrzebą osiągnięć. Obejmują one: punktualność, zamiłowanie do czystości i porządku, posłuszeństwo, uprzejmość, szczerość, lojalność, sprawiedliwość, pracowitość, potrzebę osiągnięć, oszczędność, solidność (reliability), dokładność i sumienność. Natomiast potencjalności podstawowe rozwijają się w relacjach ze znaczącymi osobami, szczególnie ojcem oraz matką, i zawierają następujące kategorie: miłość (uczuciowość i emocjonalność), model do naśladowania, cierpliwość, czas, kontakt społeczny, seksualność, zaufanie, pewność siebie, nadzieję, wiarę, zdolność do wątpienia, pewność i wewnętrzną spójność [25]. Peseschkian przyznawał, że termin ten trudno zrozumieć, ponieważ potencjalności nie jest łatwo mierzyć i nie zawsze mogą być rozpoznane na pierwszy rzut oka. Można je rozumieć jako tematy czy zagadnienia, wokół których ogniskuje się wymiana społeczna, zatem są zarówno oczekiwaniami rodziców, jak i zadaniami rozwojowymi dla dzieci, tematami sporów małżeńskich, a także porad pedagogicznych, wartościami osobistymi i normami społecznymi, w różnym stopniu usankcjonowanymi prawnie, cechami zachowania, jakich oczekujemy od siebie i innych, aspektami nas samych, z którymi się identyfikujemy, wymiarami, za pomocą których oceniamy oraz opisujemy siebie i innych. U poszczególnych osób mogą one przyjmować rozmaite formy ekspresji, mieć odmienną hierarchię i w różny sposób łączyć się ze sobą, co uzależnione jest od indywidualnych predyspozycji jednostki, momentu rozwojowego w jej życiu (jej wieku), środowiska rodzinno-społeczno-kulturowego, w jakim się wychowuje i którego wpływom podlega, oraz czasów historycznych, w jakich przyszło jej żyć. Potencjalności aktywne pełnią wiele funkcji: stanowią kategorie opisowe, zrozumiałe dla ludzi niezależnie od ich przynależności klasowej, rasowej, religijnej, zawodowej itp.; są treścią postaw, norm organizujących zachowanie członków określonych grup społecznych; są czynnikami socjalizacji, stabilizatorami ról społecznych. Jako konstrukty hipotetyczne nie są bezpośrednio obserwowalne, jednak można o nich wnioskować na podstawie konkretnego zachowania w określonym kontekście sytuacyjnym [26].

Kluczowym procesem definiującym poziom rozwoju, a zarazem wskazującym na funkcjonalność adaptacyjną potencjalności aktywnych, jest różnicowanie. Dotyczy on zasadniczo dwóch własności - treści i kontekstu. Różnicowanie to z jednej strony umiejętność poszerzania perspektywy i definiowania potencjalności na różne sposoby, czemu towarzyszy przekonanie, że każde z nich jest równie dobre czy słuszne. Na przykład zaangażowany katolik, który postępuje zgodnie z zasadami własnej wiary (m.in. w każdą niedzielę i święta uczęszcza do kościoła, czyta Biblię, zachowuje czystość przedmałżeńską i wierność jednemu małżonkowi), potrafi jednocześnie przyjaźnić się z muzułmaninem, który ma trzy żony, albo ateistą, który jest singlem, ale spotyka się z dwoma kobietami, akceptując zasadność innych wierzeń czy poglądów, albo obdarzania miłością więcej niż jednego partnera (potencjalności: wiara/sens, miłość, uczciwość). Z drugiej strony jest to umiejętność rozróżniania tego, w jakich sytuacjach dana potencjalność powinna być zrealizowana na najwyższym poziomie lub wg bardzo wąskiego standardu (w jeden konkretny sposób), a kiedy jej znaczenie jest marginalne lub sposób realizacji dowolny. Na przykład chirurg przygotowujący się do operacji powinien zawsze umyć ręce starannie i wg precyzyjnie określonego schematu (potencjalności: niezawodność, dokładność, sumienność), ale takie samo działanie 
przed spożyciem posiłku z rodziną byłoby już niepotrzebne i niewłaściwe [25, 26].

Tak więc ludzie różnią się między sobą nie tylko tym, które potencjalności są dla nich najważniejsze, ale także tym, jak je rozumieją i realizują w swoim życiu. Na ich kształtowanie ma wpływ kultura nie tylko kraju pochodzenia czy kręgu kulturowego, lecz także określonej rodziny czy grupy zawodowej. Lekarz powinien umieć rozpoznać, zrozumieć i działać adekwatnie do tego, jak szeroko rozumiana kultura danego pacjenta (pochodzenie, status ekonomiczny, przekonania religijne, przekonania zdrowotne, poziom zaufania) oddziałuje na kontekst kliniczny. Niedostrzeżenie tych istotnych czynników, niezależnie od kulturowego dystansu między lekarzem a pacjentem, wpłynie niekorzystnie na jakość pomocy [27].

\section{Narzędzie pomiarowe}

Do badania właściwości psychologicznych wykorzystano Wiesbadeński Kwestionariusz Psychoterapii Pozytywnej i Rodzinnej (Wiesbaden Inventory for Positive Psychotherapy and Family Therapy - WIPPF2) autorstwa N. Peseschkiana i H. Deidenbacha [28], w opracowaniu A. Remmersa [29] i tłumaczeniu M. Hewczuka (nie dokonano jeszcze adaptacji tego kwestionariusza dla populacji polskiej, stąd w celu porównania wyników w poszczególnych grupach autorki zdecydowały się posłużyć tłumaczeniem, mając na uwadze, iż badanie to ma charakter eksploracyjny). Kwestionariusz ten ma charakter samoopisowy - zawiera 88 itemów sformułowanych w formie zdań twierdzących, a zadaniem osoby badanej jest ocenić, w jakim stopniu zgadza się z ich treścią przy wykorzystaniu 4-stopniowej skali (tak, raczej tak, raczej nie, nie). Niektóre stwierdzenia odnoszą się do norm społecznych, przybierając formę „ogólnych prawd życiowych” (np. „Niezawodność jest szczególnie ważna w życiu zawodowym i społecznym” albo „Cierpliwością można wszystko załatwić”), inne natomiast sformułowane są w bardziej osobisty sposób (np. „Jestem czuły(a) i lubię, jak ludzie są czuli wobec mnie” albo „Potrafię czuć się dobrze także z ludźmi, którzy mają inne poglądy niż ja”). Kwestionariusz WIPPF2 zawiera 27 skal - 11 skal opisuje potencjalności wtórne, 8 skal - potencjalności podstawowe, 4 skale - reakcje na konflikt, a pozostałe 4 skale - wymiary modelowania. Wyniki kwestionariusza mogą być użyteczne na potrzeby terapii, samopoznania lub poradnictwa.

\section{Charakterystyka badanej grupy}

W badaniu, które miało charakter dobrowolny i anonimowy, wzięło udział 133 studentów Wydziału Lekarskiego Uniwersytetu Medycznego we Wrocławiu. Studenci wypełnili WIPPF2. Zebrano również dane socjodemograficzne dotyczące: wieku, płci, statusu (w związku partnerskim/wolny), obywatelstwa, obywatelstwa rodziców (matki/ojca), roku studiów. Spośród osób badanych 47 (w tym 17 mężczyzn i 30 kobiet) studiowało w języku polskim (grupa PL), a 86 było uczestnikami English Devision. Część studentów anglojęzycznych miała obywatelstwo i pochodzenie polskie, tj. oboje rodzice mieli również obywatelstwo polskie (12 osób, w tym 4 mężczyzn i 8 kobiet, grupa PL-ED), a część z tych osób miała inne obywatelstwo (grupa ED,
74 osoby, w tym 28 mężczyzn i 46 kobiet). Wyniki analizowano dla każdej z grup (PL, PL-ED, ED), a także ze względu na płeć i status.

\section{Statystyczna analiza danych}

Na potrzeby pracy analizowano wyłącznie wyniki uzyskane w skalach mierzących potencjalności aktywne (w sumie 19 skal). Normalność rozkładów badanych zmiennych sprawdzono testem Shapiro-Wilka. Rozkłady wszystkich badanych zmiennych okazały się różne od normalnego. Istotność różnic między średnimi wynikami sprawdzono za pomocą testu KruskalaWallisa z poprawką Bonferroniego. Przyjęto poziom istotności p < 0,05. Analizę statystyczną przeprowadzono za pomocą programu R (R version 3.3.1).

\section{WYNIKI}

Średnie wyniki uzyskane przez badane grupy PL, ED oraz PL-ED w poszczególnych skalach kwestionariusza WIPPF2 opisujących potencjalności pierwotne i wtórne oraz informacje o występujących między grupami różnicach zebrano w tabeli 1. Pod tabelą podano krótki opis każdej z potencjalności w ujęciu Peseschkiana [26]. Pogrubioną czcionką zaznaczono wyniki wysokie $(\geq 9,5 \mathrm{pkt})$. W badanych grupach studentów nie pojawiły się wyniki niskie $(\leq 5,5 \mathrm{pkt})$.

Jak się okazało, większość wyników uzyskanych przez badanych w skalach opisujących potencjalności aktywne mieści się w przedziale wyników średnich (tj. więcej niż 5,5 i mniej niż 9,5 pkt), co oznacza, że poziom ich zróżnicowania jest zbalansowany. Wyniki wysokie, wskazujące na silną identyfikację z daną potencjalnością aktywną, dotyczyły jedynie kilku skal, przy czym pojawiły się nie we wszystkich, lecz w wybranych grupach studentów. W obszarze potencjalności wtórnych były to: uprzejmość (w grupach ED i PL-ED), niezawodność i sprawiedliwość (tylko w grupie PL), a w obszarze potencjalności podstawowych: miłość (w grupach ED i PL-ED) i nadzieja (we wszystkich grupach). Co interesujące, w żadnej ze skal potencjalności aktywnych nie wystąpiły wyniki niskie, które wskazywałyby na niedostateczny poziom ich rozwoju (zróżnicowania).

Istotne różnice międzygrupowe odnotowano dla 7 spośród 19 potencjalności aktywnych, przy czym pojawiły się dwa wzorce tych różnic.

W odniesieniu do 3 potencjalności wtórnych (porządek, uprzejmość, posłuszeństwo) różnice wystąpiły zarówno między grupą studentów polskich i anglojęzycznych o narodowości innej niż polska, jak i między studentami polskimi oraz osobami studiującymi w języku angielskim, ale posiadającymi obywatelstwo i pochodzenie polskie. Z kolei w przypadku 2 innych potencjalności wtórnych (niezawodność i wierność), a także 2 potencjalności podstawowych (cierpliwość i kontakt), różnice wystąpiły wyłącznie pomiędzy grupami PL i ED.

Co ciekawe, studenci anglojęzyczni i badani studiujący w języku angielskim, ale posiadający obywatelstwo i pochodzenie polskie, nie różnili się w zakresie żadnej z analizowanych potencjalności aktywnych. 
TABELA 1. Średnie wyniki dla skal opisujących potencjalności aktywne w badanych grupach

Wynik wysoki/wynik średni

\begin{tabular}{|c|c|c|c|c|c|c|c|}
\hline Potencjalności aktywne & \multicolumn{2}{|c|}{$\begin{array}{c}P L \\
n=47\end{array}$} & \multicolumn{2}{|c|}{$\begin{array}{c}\text { ED } \\
n=74\end{array}$} & \multicolumn{2}{|c|}{$\begin{array}{l}\text { PL-ED } \\
n=12\end{array}$} & \multirow{2}{*}{$\begin{array}{c}\text { Istotne różnice między grupami } \\
1 \text { (PL a ED) } \\
2 \text { (PL a PLED) } \\
3 \text { (ED a PLED) }\end{array}$} \\
\hline Wtórne & średnia & SD & średnia & SD & średnia & SD & \\
\hline porządek & 6,8 & 2,3 & 8,6 & 1,7 & 9,3 & 1,2 & $1(p=0,00000) ; 2(p=0,00008)$ \\
\hline czystość & 7,6 & 1,7 & 7,5 & 2,0 & 8,4 & 2,5 & \\
\hline punktualność & 8,3 & 2,7 & 8,2 & 2,8 & 8,8 & 2,0 & \\
\hline uprzejmość & 8,7 & 2,5 & 9,9 & 1,9 & 10 & 1,1 & $1(p=0,00002) ; 2(p=0,005)$ \\
\hline otwartość/szczerość & 8,8 & 1,7 & 8,9 & 2,0 & 8,2 & 2,2 & \\
\hline pracowitość/osiągnięcia & 8,9 & 1,7 & 8,7 & 1,8 & 9,2 & 1,7 & \\
\hline niezawodność & 10,3 & 1,2 & 9,45 & 1,5 & 9,42 & 1,3 & $1(p=0,01)$ \\
\hline oszczędność & 7,5 & 2,2 & 6,8 & 2,1 & 7,9 & 1,8 & \\
\hline posłuszeństwo & 8,4 & 1,9 & 9,1 & 1,6 & 9,4 & 1,2 & $1(p=0,0009) ; 2(p=0,05)$ \\
\hline sprawiedliwość & 9,7 & 1,5 & 9,3 & 1,6 & 8,7 & 2,5 & \\
\hline wierność & 8,1 & 1,7 & 9,2 & 1,7 & 9,3 & 1,4 & $1(p=0,0005)$ \\
\hline \multicolumn{8}{|l|}{ Podstawowe } \\
\hline cierpliwość & 6,8 & 2,2 & 8,4 & 1,9 & 7,3 & 2,0 & $1(p=0,0006)$ \\
\hline czas & 8,4 & 1,8 & 8,0 & 1,6 & 8,8 & 1,1 & \\
\hline kontakt & 8,1 & 1,8 & 9,1 & 1,7 & 8,6 & 1,6 & $1(p=0,0009)$ \\
\hline zaufanie & 9,3 & 1,8 & 9,1 & 1,4 & 9,0 & 1,0 & \\
\hline nadzieja & 10,6 & 1,4 & 10,1 & 1,8 & 10 & 1,9 & \\
\hline czułość/seksualność & 8,9 & 1,7 & 8,9 & 1,8 & 8,9 & 2,0 & \\
\hline miłość & 9,4 & 1,6 & 9,8 & 1,8 & 9,7 & 1,9 & \\
\hline
\end{tabular}

Porządek - zdolność organizowania i aranżowania własnych postrzeżeń, jak również środowiska; czystość - zdolność do utrzymywania w czystości (higienie, schludności) własnego ciała, ubrania, przedmiotów codziennego użytku, otaczającego środowiska, a także charakteru; punktualność - zdolność do dostosowania się do oczekiwanego lub uzgodnionego rozkładu czasu; uprzejmość - zdolność do kształtowania relacji interpersonalnych poprzez okazywanie dobrych manier, rozpoznawanie społecznych norm zachowania, zwracanie uwagi na potrzeby innych, rozważną ekspresję; otwartość/szczerość - zdolność do bezpośredniego wyrażania własnej opinii, ujawniania potrzeb i zainteresowań oraz udzielania informacji; pracowitość/osiągnięcia - zdolność do długofalowego podtrzymywania nawet bardzo wyczerpującej aktywności w celu osiągnięcia określonego celu; niezawodność - zdolność do działania zgodnie z uzgodnieniem, tak aby nie zawieźć oczekiwań; oszczędność - zdolność do ekonomicznego wykorzystywania pieniędzy, cennych przedmiotów, zdolności, energii; posłuszeństwo - zdolność do przyjmowania próśb i słuchania poleceń zewnętrznych autorytetów; sprawiedliwość - zdolność równoważenia interesów własnych oraz interesów innych osób; wierność - zdolność do wchodzenia w długotrwałe relacje i ich utrzymywania, zachowywania się w godny zaufania sposób; cierpliwość - zdolność akceptowania siebie, innych ludzi i sytuacji takimi, jakie są; czas - zdolność do kształtowania biegu czasu oraz ustanowienia związku z przeszłością, teraźniejszością i przyszłością; kontakt - zdolność do tworzenia i kultywowania relacji społecznych; zaufanie - zdolność do oddania się w ręce innej osoby z poczuciem bezpieczeństwa; nadzieja - zdolność do rozwijania pozytywnego ustosunkowania do możliwości własnych oraz partnera czy grupy, wychodząca poza chwilę obecną; czułość/seksualność - zdolność nawiązywania seksualnej (fizycznej) relacji z sobą lub partnerem; miłość - zdolność tworzenia (pozytywnie) emocjonalnych relacji w odniesieniu do różnych obiektów; wiara/ sens - zdolność do tworzenia relacji z tym, co nieznane i niepoznawalne

TABELA 2. Potencjalności aktywne różne w grupie mężczyzn i kobiet

\begin{tabular}{lccccc}
\multirow{2}{*}{$\begin{array}{c}\text { Potencjalności } \\
\text { aktywne }\end{array}$} & \multicolumn{2}{c}{ Kobiety } & \multicolumn{2}{c}{ Mężczyźni } & p \\
\cline { 2 - 5 } & średnia & SD & średnia & SD & \\
\hline Uprzejmość & $\mathbf{9 , 6}$ & 2,1 & 8,8 & 2,4 & 0,04 \\
\hline Sprawiedliwość & $\mathbf{9 , 6}$ & 1,8 & 9,1 & 2,0 & 0,04 \\
\hline Zaufanie & $\mathbf{9 , 5}$ & 1,4 & 8,9 & 1,7 & 0,04 \\
\hline Wiara/sens & 9,0 & 2,1 & 8,0 & 2,2 & 0,006 \\
\hline
\end{tabular}

Uprzejmość - zdolność do kształtowania relacji interpersonalnych poprzez okazywanie dobrych manier, rozpoznawanie społecznych norm zachowania, zwracanie uwagi na potrzeby innych, rozważną ekspresję; sprawiedliwość zdolność równoważenia interesów własnych oraz interesów innych osób; zaufanie - zdolność do oddania się w ręce innej osoby z poczuciem bezpieczeństwa; wiara/sens - zdolność do tworzenia relacji z tym, co nieznane i niepoznawalne
Wyniki analizowano także ze względu na płeć i status badanych. Porównanie średnich w grupie kobiet i mężczyzn ujawniło występowanie istotnych statystycznie różnic w zakresie 2 potencjalności wtórnych (uprzejmość i sprawiedliwość) oraz 2 potencjalności podstawowych (zaufanie i wiara/sens). W tabeli 2 zamieszczono podstawowe statystyki opisowe (średnia, odchylenie standardowe) dla tych skal i wskazano poziom istotności statystycznej uzyskanych różnic (p). Pogrubioną czcionką zaznaczono wyniki wysokie ( $\geq 9,5 \mathrm{pkt})$.

Kobiety w wyższym stopniu opisywały siebie w kategoriach uprzejmości, sprawiedliwości, zaufania oraz wiary/sensu niż mężczyźni. Ich wyniki były nie tylko wyższe, ale i wysokie (dla 3 spośród 4 analizowanych skal), podczas gdy wyniki mężczyzn były średnie. I wreszcie wyniki kobiet cechowały 
się mniejszą zmiennością wewnątrzgrupową (podczas gdy wartości średnie dla wyżej wymienionych skal w grupie kobiet były wyższe, to jednocześnie wartości odchylenia standardowego były niższe niż w grupie mężczyzn).

Na koniec porównano wyniki osób pozostających w związkach partnerskich i osób wolnych (niebędących w związku). Istotne różnice $w$ tych grupach badanych pojawiły się w odniesieniu do 5 potencjalności aktywnych, w tym 1 potencjalności wtórnej (otwartość/szczerość) i 4 potencjalności podstawowych (kontakt, nadzieja, czułość/seksualność, miłość). W tabeli 3 podano podstawowe statystyki opisowe (średnia, odchylenie standardowe) dla tych skal i wskazano poziom istotności statystycznej uzyskanych różnic (p). Pogrubioną czcionką zaznaczono wyniki wysokie ( $\geq 9,5 \mathrm{pkt})$.

TABELA 3. Potencjalności aktywne różne u osób pozostających w związkach partnerskich i osób wolnych

\begin{tabular}{lccccc}
\multirow{2}{*}{$\begin{array}{c}\text { Potencjalności } \\
\text { aktywne }\end{array}$} & \multicolumn{2}{c}{ Osoby w związku } & \multicolumn{2}{c}{ Osoby wolne } & p \\
\cline { 2 - 5 } & średnia & SD & średnia & SD & \\
\hline $\begin{array}{l}\text { Otwartość/ } \\
\text { szczerość }\end{array}$ & 9,4 & 1,4 & 8,3 & 2,2 & 0,02 \\
\hline Kontakt & 9,4 & 1,6 & 8,6 & 1,6 & 0,01 \\
\hline Nadzieja & 10,6 & 1,3 & 9,5 & 2,1 & 0,01 \\
\hline $\begin{array}{l}\text { Czułość/ } \\
\text { seksualność }\end{array}$ & 9,6 & 1,4 & 8,4 & 2,0 & 0,002 \\
\hline Miłość & 10,2 & 1,6 & 9,3 & 1,9 & 0,02 \\
\hline
\end{tabular}

Otwartość/szczerość - zdolność do bezpośredniego wyrażania własnej opinii, ujawniania potrzeb i zainteresowań oraz udzielania informacji; kontakt - zdolność do nawiązywania i kultywowania relacji społecznych; nadzieja - zdolność do rozwijania pozytywnego ustosunkowania do możliwości własnych oraz partnera czy grupy, wychodzace poza chwilę obecną; czułość/seksualność zdolność nawiązywania seksualnej (fizycznej) relacji z sobą lub partnerem; miłość - zdolność tworzenia (pozytywnie) emocjonalnych relacji w odniesieniu do różnych obiektów

Jak się okazało, osoby pozostające w związkach partnerskich w wyższym stopniu identyfikowały się z normą otwartości/ szczerości, miały większą potrzebę kontaktu, czułości/seksualności i miłości oraz więcej nadziei niż osoby wolne. W przypadku 3 z 5 wyżej wymienionych potencjalności wyniki osób mających partnerów były wysokie; były to: nadzieja, czułość/ seksualność oraz miłość, natomiast w grupie osób wolnych wysoki wynik dotyczył tylko jednej potencjalności - nadziei.

\section{DYSKUSJA}

Wykonane badanie miało charakter eksploracyjny i dotychczas jest pierwszą próbą wykorzystania WIPPF2 na grupie studentów medycyny. Analizowano potencjalności aktywne, definiowane przez twórcę TPP jako właściwości człowieka, których ukształtowanie wymaga kontekstu społecznego i które uruchamiają się w kontakcie z innymi ludźmi, wpływając na sposób ich oceniania, komunikowania się z nimi i wchodzenia z nimi w relację [24, 25, 26]. Przyjęto, że potencjalności aktywne można ujmować jako kompetencje społeczne, przy założeniu, iż wskaźnikiem tych kompetencji jest efektywność funkcjonowania w rzeczywistych sytuacjach społecznych, a więc nie tylko skuteczność w osiąganiu celów, ale także umiejętność budowania więzi i adekwatność zachowań w stosunku do standardów społecznych [11].

Mając na celu uchwycenie ewentualnych różnic kulturowych, wyniki studentów analizowano w 3 grupach, których podstawą podziału była zadeklarowana narodowość własna i każdego z rodziców.

Jak się okazało, badani studenci w zakresie większości potencjalności aktywnych ujawnili średni poziom ich zróżnicowania, co wskazuje na prawidłowy poziom rozwoju pozwalający na elastyczne ich wykorzystanie. Znaczną identyfikację, a tym samym szczególną wrażliwość, badani ujawnili w odniesieniu do takich potencjalności jak: nadzieja (we wszystkich grupach), uprzejmość i miłość (w grupach ED i PL-ED) oraz niezawodność i sprawiedliwość (tylko w grupie PL). Wyniki te zgodne są z innymi doniesieniami. Jak wspomniano, już u kandydatów na studia medyczne ceni się posiadanie wybranych kompetencji osobistych, takich jak: odpowiedzialność, zorientowanie na pomoc innym, rzetelność i niezawodność [9]. W badaniu, w którym analizowano kompetencje społeczne praktykujących lekarzy i studentów medycyny w kontekście różnych wskaźników socjodemograficznych, większość studentów ujawniła średni poziom kompetencji społecznych zarówno w aspekcie ogólnym $(62,23 \%)$, jak i umiejętności warunkujących efektywność zachowań w sytuacjach bliskiego kontaktu interpersonalnego $(60,84 \%)$, w sytuacjach ekspozycji społecznej $(62,23 \%)$ oraz w sytuacjach wymagających asertywności $(66,43 \%)$. Wysokie wyniki w tych skalach uzyskało odpowiednio: 18,18\%, 20,97\%, 20,28\% i 10,49\% studiujących [30].

Jakkolwiek pomiędzy grupami studentów medycyny wystąpiły różnice w odniesieniu do wybranych potencjalności aktywnych, to jednak grupy ED i PL-ED nie różniły się w zakresie żadnej potencjalności. Większość różnic odnotowano dla grup PL i ED. Studenci polscy mniej (lub najmniej) w stosunku do pozostałych grup identyfikowali się z takimi potencjalnościami jak: porządek, uprzejmość, posłuszeństwo, wierność, cierpliwość i kontakt. Wyjątek stanowiła potencjalność niezawodności, z którą polscy studenci identyfikowali się najbardziej, a co więcej - wyjątkowo silnie. Biorąc pod uwagę sposób rozumienia tych potencjalności w koncepcji Peseschkiana [26], zwraca uwagę fakt, iż badani studenci polscy w porównaniu z osobami studiującymi w języku angielskim w mniejszym stopniu opowiadali się za sposobami funkcjonowania, w których tworzenie relacji odbywa się poprzez kierowanie uwagi na właściwości czy potrzeby kogoś innego, a nie na własną sprawczość czy samokontrolę. Możliwe, iż ten układ wyników jest specyficzny dla kultury polskiej lub też wynika z mniej intensywnego treningu społecznego w zakresie kontaktów międzykulturowych, jednak potwierdzenie takiej hipotezy wymagałoby pogłębionych badań.

W badanej grupie ujawniły się również różnice płciowe oraz związane z pozostawaniem w związku partnerskim.

Kobiety przywiązywały większą wagę do uprzejmości, sprawiedliwości, zaufania oraz wiary/sensu niż mężczyźni, ponadto 
były to dla nich obszary szczególnej wrażliwości (z wyjątkiem potencjalności wiara/sens). Wynik ten można tłumaczyć odmiennością oddziaływań socjalizacyjnych dotyczących ról społecznych w grupie mężczyzn i kobiet, gdyż w większości kultur dziewczynki i kobiety w większym stopniu niż chłopców i mężczyzn zachęca się do nawiązywania relacji na płaszczyźnie emocjonalnej i w oparciu o współpracę [31]. W cytowanej powyżej pracy kobiety wykazały większą umiejętność radzenia sobie w sytuacjach bliskiego kontaktu interpersonalnego oraz ekspozycji społecznej, a zarazem mniejszą w sytuacjach wymagających asertywności niż mężczyźni [29].

Pozostający w związkach, w porównaniu z osobami wolnymi, nadawali większe znaczenie obszarom opisywanym przez potencjalności podstawowe, wskazującym na zdolność do tworzenia i utrzymywania bliskich relacji, takim jak: otwartość/szczerość, kontakt, czułość/seksualność, miłość, nadzieja. Potencjalności podstawowe są tymi, które rozwijają się z wrodzonej ludziom zdolności do kochania, troszczenia się o innych. Prezentowane badanie nie pozwala na stwierdzenie, czy bazowa większa aktywność wymienionych potencjalności motywuje studentów do budowania związków partnerskich, czy też pozostawanie w związku na tyle aktywizuje potencjalności pierwotne, że stały się one bardziej aktywne w tej grupie osób.

\section{WNIOSKI}

Uzyskane wyniki sugerują, iż kształcenie zawodowe w zróżnicowanym kulturowo środowisku akademickim może przyczynić się do wykształcenia większej wyrozumiałości dla różnorodności będącej elementem kompetencji kulturowej. Stąd, szczególnie w grupie studentów polskich, postuluje się włączenie w proces edukacji przyszłych lekarzy wiedzy na temat innych kultur oraz rozbudzanie postawy ciekawości i otwartości wobec kulturowych uwarunkowań zdrowia pacjenta.

\section{PIŚMIENNICTWO}

1. White R. Motivation reconsidered: the concept of competence. Psychol Rev 1959;66(5):297-333.

2. Rozporządzenie Ministra Nauki i Szkolnictwa Wyższego z dnia 9 maja 2012 r. w sprawie standardów kształcenia dla kierunków studiów: lekarskiego, lekarsko-dentystycznego, farmacji, pielęgniarstwa i położnictwa. DzU, poz. 631.

3. Bankiewicz-Nakielska J, Tyszkiewicz-Bandur M, Walkiewicz M, Karakiewicz B. Kompetencje psychologiczne w pracy lekarza. Med Dypl 2017;26(1):108-14

4. Bryl N, Horst-Sikorska W, Ignaszak-Szczepaniak M, Marcinkowska M, Michalak M, Sewerynek E. Influence of social competence of physicians on patient compliance with osteoporosis medications - a study on Polish postmenopausal women. Ginekol Pol 2012;83(7):511-6.

5. Pereira-Limaab K, Loureiro S. Burnout, anxiety, depression, and social skills in medical residents. Psychol Health Med 2015;20(3):353-62.
6. Gordon T, Edwards W. Rozmawiać z pacjentem. Podręcznik doskonalenia umiejętności komunikacyjnych i budowania partnerskich relacji. Wskazówki dla: lekarzy, personelu medycznego, wolontariuszy, rodziny chorego. Warszawa: Academica; 2009.

7. Cole S, Bird J, editors. The medical interview: the tree-functional approach. 3rd ed. Philadelphia: Elsevier Saunders; 2014.

8. Kurtz S, Silverman J, Draper J. Teaching and learning communication skills in medicine. 2nd ed. Oxford - San Francisco: Radcliffe Publishing; 2009.

9. Koening T, Parrish S, Terregino C, Williams J, Dunleavy D, Volsch J. Core personal competencies important to entering students' success in medical school: what are they and how could they be assessed early in the admission process? Acad Med 2013;88(5):603-13.

10. Bankiewicz-Nakielska J, Tyszkiewicz-Bandur M, Karakiewicz B. Wiedza i umiejętności psychologiczne kluczowe w pracy lekarza - badanie eksploracyjne. Med Health Sci Rev 2016;2(2):51-5.

11. Martowska K. Psychologiczne uwarunkowania kompetencji społecznych. Warszawa: Liberi Libri; 2012.

12. Matczak A. Kwestionariusz Kompetencji Społecznych KKS. Podręcznik. 2nd ed. Warszawa: Pracownia Testów Psychologicznych PTP; 2012.

13. Martowska K, Matczak A. Pomiar kompetencji społecznych - prezentacja nowego narzędzia diagnostycznego. Psychologia Jakości Życia 2013;12(1):43-56.

14. Smółka P, Szulawski M. Personality traits and motivational traits as predictors of social competence. Implication for occupational selection process. Edukacja Ekonomistów i Menedżerów 2011;4(22):111-26.

15. Martowska K. Temperamental determinants of social competencies. Pol Psychol Bulletin 2014;45(2):128-33.

16. Novack DH. Use of the Self in Medical Care. In: Cole S, Bird J, editors. The medical interview: the tree-functional approach. 3rd ed. Philadelphia: Elsevier Saunders; 2014. p. 270-5.

17. Steele D. Culturally competent medical interviewing. In: Cole S, Bird J, editors. The medical interview: the tree-functional approach. $3 \mathrm{rd}$ ed. Philadelphia: Elsevier Saunders; 2014. p. 172-81.

18. Sorensen J, Norredam M, Dogra N, Essink-Bot M-L, Suurmond J, Krasnik A. Enhancing cultural competence in medical education. Int J Med Educ 2017;8:28-30. doi: 10.5116/ijme.587a.0333.

19. Zayapragassarazan Z, Kumar S. Emotional intelligence and medical professionalism. NTTC Bulletin 2011;18(2):3-4.

20. Kostadinova I, Antonova D. Integrated system for improving professional competence taking into account the impact of emotional and social intelligence on doctors’ practice. Analele Universitatii ‘Eftimie Murgu’ Resita. Fascicola II. Studii Economice 2014. p. 88-101.

21. Lindberg 0 , Rantatalo 0 . Competence in professional practice: A practice theory analysis of police and doctors. Hum Rel 2015;68(4):561-82.

22. Ciesielski R. Transkulturowa Psychoterapia Pozytywna jako zintegrowany system terapeutyczny. Wrocław: Wydawnictwo Continuo; 2015.

23. Dobiała E, Winkler P. 'Positive psychotherapy' according to Seligman and 'Positive Psychotherapy' according to Peseschkian: A Comparison. Int J Psychotherapy 2016;20(3):5-17.

24. Ciesielski R. Potencjalności aktywne, mikrotraumy i analiza różnicowa. Wrocław: Wydawnictwo Continuo; 2016.

25. Peseschkian N. Pozytywna Terapia Rodzin. Rodzina w roli terapeuty. Wrocław: Wydawnictwo Continuo; 2015.

26. Peseschkian N. Positive Psychotherapy. Theory and practice of a new method. Berlin, Heidelberg, New York, London, Paris, Tokyo: SpringerVerlag; 1987.

27. Betancourt JR. Cultural competence and medical education: many perspectives, one goal. Acad Med 2006;81(6):499-501.

28. Peseschkian N, Deidenbach H. Wiesbadener Inventarzur Positiven Psychoterapie und Familientherapie (WIPPF). New York: Springer-Verlag; 1988. p. 128-276.

29. Remmers A. Inventory for Positive Psychotherapy and Family Therapy WIPPF2.0, 1995, 2009. International Version.

30. Mroczek B, Zarek A, Rudnicki J, Wolińska W, Pawlak I, Dyk T, et. al. Social competence of physicians and medical students - a preliminary report. Fam Med Primary Care Rev 2016;18(3):308-12.

31. Ciccarelli S, White N. Psychologia. Poznań: Rebis; 2015. 